\title{
AQUATIC INFLUENCE ON MOBILITY OF A CHILD WITH DUCHENNE MUSCULAR DYSTROPHY: CASE STUDY
}

\author{
Samuel Honório \\ Instituto Politécnico de Castelo Branco; RECI; Portugal, (samuelhonorio@ipcb.pt) \\ Marco Batista \\ Instituto Politécnico de Castelo Branco; RECI; Portugal, (marco.batista@ipcb.pt) \\ Rui Paulo \\ Instituto Politécnico de Castelo Branco; RECI; Portugal, (ruipaulo@ipcb.pt) \\ Pedro Mendes \\ Instituto Politécnico de Castelo Branco; RECI; Portugal, (pedromendes@ipcb.pt) \\ Jorge Santos \\ Instituto Politécnico de Castelo Branco; Portugal, (jorge.santos@ipcb.pt) \\ João Serrano
}

Instituto Politécnico de Castelo Branco; FCT and CI\&DETS (PEst-OE/CED/UI4016/2011)

Portugal, (j.serrano@ipcb.pt)

João Petrica

Instituto Politécnico de Castelo Branco; FCT and CI\&DETS (PEst-OE/CED/UI4016/2011)

Portugal, (j.petrica@ipcb.pt)

Helena Mesquita

Instituto Politécnico de Castelo Branco,Portugal, (hmesquita@ipcb.pt)

António Faustino

Instituto Politécnico de Castelo Branco,Portugal (afaustino@ipcb.pt)

Júlio Martins

Sports Science Department - Human and Social Sciences Faculty - University of Covilhã (CIDESD), Portugal (jmartins4@gmail.com) 
Aquatic Influence on Mobility of a Child with Duchenne Muscular Dystrophy: Case Study

\begin{abstract}
The study was initiated because one of the authors had a child in the family with Duchenne muscular dystrophy (DMD). The author was concerned about what could be done to improve the quality of life of this child. The hypotheses explored whether hydrotherapy could bring any relief or advantage in functional mobility to an individual with DMD and whether a water environment facilitates mobility, pleasure, and joy for a young child with Duchenne muscular dystrophy. Our sample had three individuals, all of them boys, 9-11 years of age. Two were the control group and didn't practice any kind of physical activity and the other one was our two-year longitudinal case study during which he experienced hydrotherapy practice two times a week for forty-five minutes each. We applied the Egen Klassifikation (EK) scale to quantify the degree of movement limitation present at each of five measurement points over the two years. The variables analyzed were the physical activity issues and the EK scale values. The descriptive results showed that all three individuals increased their EK scale values over time, showing the inevitable progression of the disease. The individual who participated in the water activity sessions had the slower increase that we inferred, meant less deterioration in functional movement. No inferences can be drawn from these limited data, especially because only one individual experienced the water activities. This study does provide the impetus for subsequent, larger controlled studies to see if they could replicate these initial case study results.
\end{abstract}

Keywords: Duchenne muscular dystrophy, aquatic therapy, functional mobility, hydrotherapy 


\section{Introduction}

Muscular dystrophies represent a group of at least nine hereditary diseases which are characterized by severe, progressive, and irreversible atrophy of the muscles. The Duchenne muscular dystrophy (DMD) is the most common type of all these dystrophies which occurs in childhood between three and four years of age. Its etiology is progressive and leads to muscular weakness, functional limitations, skeletal deformities, impact of cardiac musculature and a decrease the vital respiratory capacity. The current intervention regarding exercise is essentially based on hydrotherapy which may improve mobility, reduce impact of disability, prevent complications and above all prevent muscle contraction. For certain objectives, in order to achieve therapeutic success it's necessary to evaluate the severity of functional impairment of patients with DMD. In this context, the uses of scales that measure the functional ability of their daily activities have a crucial importance.

The lack of regular physical activity can promote rapid loss of function in the cardiac and respiratory systems. Physical activity programming based on thorough functional assessments for DMD patients is crucial to maintain the quality of life of these children used in conjunction with other associated resources whenever possible, Guerrero (2007). These interventions can relieve pain, address muscle-skeletal malformations, and maintain some basic functional skills.

\section{Review of Literature}

The groups of nine muscular dystrophy (MD) diseases are caused by an absence of or inability to produce the dystrophyne protein. The lack of this protein destroys the membranes of muscle cells and does not allow normal functionality of skeletal and cardiac muscles. The presence of scoliosis is a frequent side effect and may be a factor in thoracic deformities. 
Children afflicted by DMD often are able to maintain an independent walking gait until six or seven years of age although this age definitely has individual differences. Normally children with DMD don't live to reach a full adult lifespan because they die of chronic alveolar hypoventilation or aggressive chronic myocardiopathy (Zatz, 1986). This diagnosis is established by family history using genetic and clinical tests. The most common clinical diagnostic test is the muscular biopsy.

Currently, no known treatments exist that can block or reverse the DMD process; however, there are some therapeutic options that may provide some kind of relief in functional terms. One of the most important therapies is hydrotherapy (Caromano, 2004; Ovando, 2008). This resource has been very useful because of the physical density and specific gravity properties of water which allow buoyancy to support the body and makes mobility easier. As a consequence, water buoyancy promotes the muscular relaxation of extensor ("anti-gravity") muscle groups and increases the range of motion around a wide variety of joints, especially in the lower extremities. Such mobility in the water can provide a sense of freedom, joy, and satisfaction allowing individuals to accomplish tasks they otherwise could not outside the water. It is recommended that most water activities for individuals suffering from MD take place in a warm swimming pool $\left(28^{\circ}-30^{\circ} \mathrm{C}\right.$ or $\left.82^{\circ}-87^{\circ} \mathrm{F}\right)$ so they can maintain the frequency and rate of movement at various joints, maintain muscular strength, balance, and breathing capacity without being chilled.

\section{Methods}

\section{Sample Selection}

This study uses a quasi-case study approach with a sample of three individuals, all of them male between the ages of nine and eleven years. Each suffered from the DMD type of MD. 
All individuals and their family members signed an informed consent. The study was approved by the Ethics Committee of the University, with the reference 04/2014.

\section{Instrumentation (EK scale)}

The Egen Klassifikation (from the Danish: "meaning our own classification") (EK) is a functional motor scale developed in Denmark to quantify the degree of motor functionality, indicating how much limitation an individual has both in and out of the water, for MD patients. The EK has been used as a method to discriminate several, distinct levels of performance in activities of daily living. The EK scale consists of ten questions, each of which is measured on a scale from 0 to 3 , with a total possible value ranging between 0 to 30 . Higher scores represent the most severe degree of motor limitation. Currently, no validity or reliability for the EK scale has been published, but needs to if it is going to be more widely used for research purposes.

We administered the EK scale on five occasions to all patients so that we could quantify each of their functional movement limitations. The multiple testing occasions allowed for determining reliable values of movement limitation on the 0-30 EK scale (see Table 1).

Table 1 - Comparison of EK scale values between individuals regarding all five evaluations.

\begin{tabular}{ccc}
\hline Group & Evaluation & EK scale \\
\hline \multirow{3}{*}{$\begin{array}{c}\text { Practitioner of } \\
\text { water activities }\end{array}$} & $1 \mathrm{st}$ & 9 \\
\cline { 2 - 3 } & $2^{\text {nd }}$ & 11 \\
\cline { 2 - 3 } & $3^{\text {rd }}$ & 13 \\
\cline { 2 - 3 } & $4^{\text {th }}$ & 15 \\
\hline \multirow{3}{*}{$\begin{array}{c}\text { Non - Practitioner } \\
\text { of water activities }\end{array}$} & $5^{\text {th }}$ & 18 \\
\cline { 2 - 3 } (Individual One) & $2^{\text {nd }}$ & 9 \\
\cline { 2 - 3 } & $3^{\text {rd }}$ & 12 \\
\cline { 2 - 3 } & $4^{\text {th }}$ & 18 \\
\hline Non - Practitioner & $5^{\text {th }}$ & 21 \\
\cline { 2 - 3 } of water activities & $1 \mathrm{st}$ & 8 \\
\hline
\end{tabular}




\begin{tabular}{lll}
\hline (Individual Two) & $3^{\text {rd }}$ & 14 \\
\cline { 2 - 3 } & $4^{\text {th }}$ & 16 \\
\cline { 2 - 3 } & $5^{\text {th }}$ & 20 \\
\hline
\end{tabular}

\section{Procedures (Exercising program)}

During this study we developed and applied an exercise program with the main objective to provide functional mobility with water activities over several sessions.

Two of the individuals didn't engage in any exercise activities, but the other one participated in 45 minute water exercise sessions one and/or two times a week for 89 weeks.

\section{Statistical Analysis}

We initially calculated descriptive statistics (i.e., means and station deviations) for the values of the EK measure across all 5 time periods. We also compared the descriptive values between the single water exercise practitioner and the two control individuals for the first to fifth evaluations trying to determinate whether there was any influence on the EK values from the water activity sessions, and also conducted the One Sample t-test, with confidence intervals in order to try to establish that purpose (see table 3).

Table 2 - Comparison of std. deviation and mean values of EK scale variable, from the first to fifth evaluation between individuals.

\begin{tabular}{|c|c|c|c|c|c|c|}
\hline Group & & Ev. EK 1 & Ev. EK 2 & Ev. EK 3 & Ev. EK 4 & Ev. EK 5 \\
\hline \multirow{3}{*}{$\begin{array}{l}\text { Non - } \\
\text { Practitioner } \\
\text { Group of PA/H }\end{array}$} & Mean & 8.5000 & 11,5000 & 14,5000 & 17,0000 & 20,5000 \\
\hline & $\mathrm{N}$ & 2 & 2 & 2 & 2 & 2 \\
\hline & $\begin{array}{l}\text { Std } \\
\text { Deviation }\end{array}$ & 1,41421 & 2,12132 & 2,12132 & 2,12132 & 2,82843 \\
\hline \multirow{3}{*}{$\begin{array}{l}\text { Practitioner } \\
\text { Individual of } \\
\mathrm{PA} / \mathrm{H}\end{array}$} & Mean & 9,0000 & 11,0000 & 13,0000 & 15,0000 & 18,0000 \\
\hline & $\mathrm{N}$ & 1 & 1 & 1 & 1 & 1 \\
\hline & $\begin{array}{l}\text { Std } \\
\text { Deviation }\end{array}$ & . & . & . & . & . \\
\hline \multirow{3}{*}{ Total } & Mean & 6,7143 & 8,8571 & 10,2857 & 12,4286 & 14,1429 \\
\hline & $\mathrm{N}$ & 3 & 3 & 3 & 3 & 3 \\
\hline & $\begin{array}{l}\text { Std } \\
\text { Deviation }\end{array}$ & 4,34796 & 4,29839 & 4,42396 & 4,46681 & 4,91354 \\
\hline
\end{tabular}


Table 3 - Values of the One Sample t-test analysis, relating the confidence intervals between individuals, in all five evaluations.

\begin{tabular}{|c|c|c|c|c|c|c|}
\hline & \multirow[t]{2}{*}{$\mathrm{t}$} & \multirow{2}{*}{$\begin{array}{l}\text { Practitioner of } \\
\text { water activities }\end{array}$} & \multirow{2}{*}{$\begin{array}{l}\text { Sig. (2- } \\
\text { tailed) }\end{array}$} & \multirow{2}{*}{$\begin{array}{c}\text { Non - } \\
\text { Practitioner } \\
\text { Group of } \\
\text { PA/H }\end{array}$} & \multicolumn{2}{|c|}{$\begin{array}{l}95 \% \text { Confidence } \\
\text { Interval of the } \\
\text { Difference }\end{array}$} \\
\hline & & & & & Lower & Upper \\
\hline Ev1EK & 17,000 & 9 & ,037 & 8,50000 & 2,1469 & 14,8531 \\
\hline Ev2EK & 23,000 & 11 & ,028 & 11,50000 & 5,1469 & 17,8531 \\
\hline Ev3EK & 29,000 & 13 & ,022 & 14,50000 & 8,1469 & 20,8531 \\
\hline Ev4EK & 17,000 & 15 & ,037 & 17,00000 & 4,2938 & 29,7062 \\
\hline Ev5EK & 41,000 & 18 & ,016 & 20,50000 & 14,1469 & 26,8531 \\
\hline
\end{tabular}

We initially had intended to perform a non-parametric statistical analysis with the Wilcoxon and Mann-Whitney "U” tests using the Statistical Package for the Social Sciences (SPSS 17) program at a significance level of $p \leq 0.05$. Unfortunately, we learned that because our water exercise/therapy group had only one member, it is not possible to conduct any inferential statistical analyses. We had to rely on the descriptive statistics and One Sample t-test.

\section{Results}

Table 2 indicates that EK scale values gradually increased from the first to the fifth evaluations for both groups; however, the increases in the scores from the individual who participated in the water sessions was descriptively less than for the two control persons who did not receive water treatment. Because of the lack of a sufficient sample (i.e., more than one person needs to be in any group) we could not calculate any inferential or non-parametric statistics or draw any conclusions that extend beyond these three individual cases.

From the interpretation of table 3 , its observable that before the confidence interval forecasted for the lower and upper limit of the difference of means, the average of Non Practitioner Group as well as the Practitioner of water activities are between those limits. This inference suggests that both groups are fitted in an apparently normal scale parameter for each 
of the five evaluations. But we found that the data collected, made in time series, there is a delay in the advancement of EK scale on the individual with water activities. So, it's prudent to suggest a benefit, slowing the dystrophic degeneration of the individual in a more obvious way, in addition to individuals in the same ambulatory gait profile, once they do not have practice of any kind.

\section{Discussion}

After analyzing the results we are determined to assure that implemented water sessions did not significantly improve this child mobility, however, they also did not cause any kind of negative effects as well.

From this results, we can report that water activities did not improve the performance of daily activities in this individual according to the EK which is presented on Table 2, namely, in the and last evaluation that contemplated the two years study. However, it reveals an apparently greater (but not statistical) difference between EK scale values for those who did not experience hydrotherapy.

Therapeutic activities in the water environment as became a positive attitude in approaching these individuals, where the water is considered a safety and efficient environment, and doesn't represent an overload to the patient. On the contrary, provides an enjoyable place where they feel happiness (Caromano, et al. 1998; Caromano, 2004). Water activities are a positive response in children with DMD, because they are able to perform several activities with less pain and more muscular relaxation (Ovando, 2008) as they engage in a pleasant, independent, and motivational activity.

Water activity also did not provide any negative side effects. Compared with the two non-hydrotherapy participants, the descriptive values on the EK scale seemed to be lower, 
although without multiple participants, no valid statistical comparison is possible. These data show some similarities to the findings of Mok (2008) where water activities brought advantages, not only in daily activities but also in their general mobility.

It is a fact that muscle degeneration increases as they get older. Because the degeneration process in not reversible, they get more limited as they increase their age. Variables such as BMI, fat mass percentage, and types of physical activity can alter and be influent in the process of the degeneration speed. Younger children are the ones who, sometimes, can perform some tasks alone and with very low values of EK, as stated in Ramacciotti and Nascimento (2009) study, in which the 6 year old individual had no significant limitations and still able to walk and perform some tasks with support. The Berard (2005) study found that individuals who did not had any type of physical activity had EK scale values much higher, as well as Okama (2010).

The implemented physical activity (hydrotherapy) was based on the criteria mentioned in the literature, in terms of water temperature, duration of time sessions and type of exercises.

Although it didn't brought significant improvements brought no harm as well, and had influence in decreasing Ek scale values lower than the group without any type of physical activity. This show's some compliance with Vitorino (2004) study, who has shown that hydrotherapy bring advantages not only in terms of ADL (Activities of Daily Living) but also in mobility, which is revealed in our fifth evaluation showing the biggest difference between EK scale values .

"On the other hand, the absence of normal physical activity results in a loss of function of several organ systems such as, for example, the cardio-respiratory systems. Today, it is known that physical activity programming for DMD patients when performed based on a 
thorough functional assessment is critical to maintaining the quality of life of these children should be used as well as other associated resources when needed, as indicated of orthotics or use of hydrotherapy...” (Caromano, 1999, p. 217). Bushby (2005, p. 296) also stated that ... "the children should be encouraged to develop activities that promote functionality, such as active exercise, particularly hydrotherapy in heated water, and is recommended because encourages the child to play by themselves and interacts with those who are close to them."

Campion (2009) have evaluated the effects of immersion in heated water with 20 male DMD children, aged between 8 and 15 years. The variables analyzed were heart rate (HR), O2 saturation, Maximal Inspiratory Pressure (MIP), and Maximal Expiratory Pressure (MEP). These changes were clinically relevant, between the periods of pre-immersion and immersion, showing an increase average value of $3.8 \mathrm{~cm}$ of water in the amount of maximal inspiratory capacity. Maximal expiratory pressure obtained between the pre-immersion and immersion an initial increase of $7.4 \mathrm{~cm}$ of water and subsequently between periods of immersion. This study showed that "Hydrotherapy is a therapeutic resource that is not a burden for children with Duchenne muscular dystrophy." (Campion, 2009, p. 2)

Brito et al. (2010) conducted a study, very similar to ours, also with a sample of three individuals with DMD aged between 9 to 22 years old, where the main purpose was to verify the influence of hydrotherapy and its effects on respiratory muscle capacity. For this purpose 17 sessions of hydrotherapy were conducted for 45 minutes, twice per week (duration and frequency equal to our study). Despite the limitations imposed by the progressive nature of the disease to the clinical conditions of individuals in terms of breathing, hydrotherapy and the resulting physical properties of water, the pain was relieved and movements facilitated. The objectives were achieved in increasing muscle strength and respiratory vital capacity performed in an aquatic environment for DMD patients. The performed activity brought 
positive features, which increased the life quality of these patients through improvement of the respiratory capacity.

Finally, we mention another case study of Sales et al. (2004) with a 10 year-old boy which also used hydrotherapy for breathing exercises effects. The aim of the study was maintaining and stimulating the respiratory ability carried out once a week for 30 minutes. The boy performed inspirations and expirations in water so that the water exerted pressure against the rib cage. After 6 sessions ( 1 per month for 6 months) there was an increase of 1.5 $\mathrm{cm}$ in chest perimeter, as well as an improvement in breathing capacity, indicating an improvement which allowed a broader expansion of the lungs much more effective.

In conclusion, we might say in a prudent way that physical activity/hydrotherapy in DMD patients provides positive influences in order to reduce the motor limitations that interfere in their daily activities despite we didn't find any significant statistical differences between evaluations. So, water activities, carefully planned, didn't block the limitation process, but was able to slow it down, as stated in our results.

Acknowledgments: The authors would like to express the most sincere thanks to the children and parents involved in this study.

\section{References}

1) ACSM (2001). Resource Manual for Guidelines for Exercise Testing and Prescription. Baltimore MD: Exercise and Sport Sciences Editorial Service.

2) Abreu, S. (1999). Distrofia Muscular de Duchenne - Do Gene à Reabilitação, 6 (21), 27-43. Arquivos de Fisiatria, Hospital Pediátrico - Coimbra.

3) APN (2007). “A (d)eficiência no acompanhamento dos Doentes Neuromusculares - da expressão dos doentes e famílias à construção das respostas sociais". Revista 47, Porto: Debate Aberto. 
4) Brito, R., Lopes, R., Parreira, V. (2010). Treinamento muscular respiratório em pacientes portadores de distrofia muscular de Duchenne no ambiente aquático. Brasil: UNESC.

5) Caromano, F. (1998). Efeitos Fisiológicos de Sessão de Hidroterapia em Crianças Portadoras de Distrofia Muscular de Duchenne. Revista Fisioterapia U.S.P, 5(1), 49-55.

6) Caromano, F. (2004). Revisão e actualização da graduação da resistência ao movimento durante a imersão da água. Revista Fisioterapia. USP, vol. 5(11). São Paulo, Brasil;

7) Caromano, F., Ambrosio, C. E. (2010). Correlação entre a massa de gordura corporal, força muscular, pressões respiratórias máximas e função na Distrofia Muscular de Duchenne. Revista Conscientiae, 9(10), São Paulo, Brasil;

8) Caromano, F. (1999). Charateristics of the Duchenne's muscular dystrophy (DMD) patient. A review Arq. Sciences Unipar. Jaguaré, SP: Brazil;

9) Downie, P. (1997). Neurologia para fisioterapeutas. Medicina Panamericana. Editora do Brasil: 403423.

10) Dubowitz, V. (1989). A color atlas of muscle disorders in childhood. London: Wolfe Medical Publication.

11) Emery, A. (2000). The muscular distrophies. The Lancet, Vol 359. London, UK;

12) Essex, C. (2001). Late diagnosis of Duchenne's muscular dystrophy presenting as global developmental delay. BJM Clinical Review, 323, 39-52.

13) Fabris, S. (2005). Distrofia Muscular de Duchenne: Aspectos clínicos relevantes para a intervenção terapêutica. Edições Medicina e Saúde, Filho, J, Reis. V. (2006). Manual de Antropometria. São José de Rio Preto, São Paulo - Brasil: Edições e Serviços Gráficos UTAD, Vila Real de Trás-os-Montes;

14) Ledoux, P. (1995). Kinésithérapie de L’enfant paralysé - Spina bífida, amuotrophies spinales infantiles, myopathie de Duchenne de Boulogne. Illustration de Collection de Kinésithérapie Pédiatrique: ParisFrance.

15) Lohman, T., Pires, N., \& Petrosky, H. (1986). Applicability of body composition techniques and constants for children and youth. Exercise and Sports Science Review, 14, 325-357.

16) Marques, M. (2007). O esforço da ciência para decifrar a distrofia muscular de duchenne. Jornal da Unicam, SP-Brasil: Universidade Estadual de Campinas. 
17) Martinez, J., Brunherotti, M. A., Assis, M. R., Sobreira, C.R. (2006). Validação da Escala Motora Funcional EK para a Língua Portuguesa. Revista da Associação Médica Brasileira, 52 (5), 347-51.

18) Mok, E., Thelen, K. M., Riemer, C. (2006). Estimating body composition in children with Duchenne muscular dystrophy : comparison of bioelectrical impedance analysis and skinfold-thickness measurement. The American Journal of Clinical Nutrition, 83(1), pp. 65-69.

19) Nair, S. (2001). Disabilities in Children with Duchenne Muscular Dystrophy: A Profile. Journal of Rehabilition Medicine; 33,147-149.

20) Okama, L., Queiro, P.D., Spina, L.R., Miranda, M.B., Curtarell, M.B., Faria, M. (2010). Avaliação funcional e postural nas distrofias musculares de Duchenne e Becker. ConScientiae Saúde, 9(4), 649658.

21) Ovando, A. (2008). A hidroterapia como forma de tratamento para Distrofia Muscular de Duchenne: relato de caso. Revista Efdeportes, Ano 13, $n .{ }^{\circ}$ 126, Buenos Aires-Argentina;

22) Pires, N., \& Petrosky, E. (1996). Desenvolvimento e validação de equações generalizadas para estimativa da densidade corporal. Rio Grande do Sul, Brasil: Universidade Federal Santa Maria,

23) Pollock, M., Shmidt, D. \& Jackson, A. (1980). Measurement of the cardiorespiratory fitness and body composition in the clinical setting. Compr. Ther., 6, 12-27.

24) Ramaccioti, E., \& Nascimento, C. (2009). Efeito do exercício resistido na função motora do paciente com Distrofia Muscular de Duchenne. Revista neurociência 18(3): 341-346.

25) Silva, A., Reis, V., Filho, J., Fernandes, P. (2006). Manual de Antropometria. UTAD-Serviço Editorial, Vila Real;

26) Sales, I., Araujo, F.P., Neves, J.F. (2004). Efeitos de exercícios físicos em piscina sobre a função pulmonar do portador de distrofia muscular de duchenne. Um relato de caso. Arq. Ciênc. Saúde Unipar, Umuarama, 8 (1), 67-72.

27) Swann-Guerrero, S. (2007). Potential Benefits of Exercise. College of Applied health sciencesdepartment of disability and human development. UIC, Chicago, USA.

28) Willig, L. (1997). Body composition determined with MR in patients with Duchenne muscular dystrophy, spinal muscular atrophy, and normal subjects. Elsevier,15( 7), 737-744.

29) Zanardil, L., Pascual, F.B., Bisgard, K., Murphy, T. (2002). Body composition and energy expenditure in Duchenne muscular dystrophy. Pavia - Italy: University Research Centre. 
30) Zitteli, B., \& Davis, H. (1992). Atlas Colorido de Diagnóstico Clínico em Pediatria (2ª edição). São Paulo, Brasil: Editora Manole. 